\title{
Cut Off Value of Procalcitonin In End Stage Renal Disease Patients Without Infection
}

\author{
Naila Asif, Samina Shamim, Shafqat Waqar Khanzada, Muhammad Rizwan \\ Liaquat National Hospital and Medical College, Karachi, Pakistan
}

\begin{abstract}
:
Hemodialysis (HD) is considered as a proinflammatory state and therefore associated with release of inflammatory cytokines and acute phase reactant proteins. The conventional laboratory markers (C-reactive protein, erythrocyte sedimentation rate) are efficient tools for the diagnosis of infection in patients with normal kidney functions. However, they can be nonspecifically elevated in patients undergoing $\mathrm{HD}$ and only reflect inflammatory response rather than presence of infection. procalcitonin (PCT) is considered a very important biomarker in differentiating infections from inflammation. The study was undertaken to evaluate normal serum levels of PCT in patients undergoing HD.

Patients and Method: The study included 82 end-stage renal failure patients without evidence of systemic or localized infection undergoing maintenance HD.

Results: In our study, the PCT concentrations showed a mean of $.622 \mathrm{ng} / \mathrm{ml}$ in patients on maintenance HD without signs of infection.

Conclusion: The study suggests that a higher normal serum PCT at a cutoff value of $.62 \mathrm{ng} / \mathrm{ml}$ should be considered in maintenance HD patients.
\end{abstract}

Keywords: Procalcitonin, HD, sepsis, infection, acute phase reactants, $\mathrm{C}$ reactive protein, Erythrocyte sedimentation rate.

\section{Introduction:}

Procalcitonin (PCT) was first introduced by Assicot in 1993, is considered as a diagnostic marker of sepsis. ${ }^{1}$ PCT has been reported as an important biomarker in distinguishing bacterial infections from nonbacterial infections such as viral infections and systemic inflammatory response syndrome (SIRS). ${ }^{2}$ ${ }^{4}$ It is a polypeptide with 116 amino acids and has a molecular weight of $13 \mathrm{kDa}$. Increased levels of serum PCT have also been reported in localized bacterial infections. ${ }^{5}$ On the basis of these findings, PCT is now recognized as an important tool for the early diagnosis of bacterial infections. Multiple studies also show that most important strategy for sepsis treatment is early recognition and implementation of timely treatment. ${ }^{6.7} \mathrm{PCT}$ has also been proven as an effective modality in tailoring antibiotic treatment for respiratory tract infections, thus helping to reduce antibiotic adverse effects and resistance. ${ }^{8}$ On the basis of these findings, PCT is now recognized as an important modality for the diagnosis of bacterial infections. However, the use of PCT as bacterial diagnostic marker in chronic kidney disease (CKD) patients is controversial. ${ }^{9.11}$

Bacterial infections are recognized as a major cause of morbidity and mortality in patients undergoing hemodialysis (HD). ${ }^{12}$ Currently there has been shifting of paradigm in the treatment of infections, mainly switching away from invasive monitoring and targeting on early fluid resuscitation 
and antibiotics. So timely and prompt detection of bacterial sepsis is cornerstone of therapy and is crucial to improve the outcome. HD in end stage kidney disease (ESKD) patients is considered as a pro inflammatory state, as it induces inflammatory response, the etiology of which is multifactorial. ${ }^{13,14}$ There can be patient-related factors such as underlying pathology, comorbid conditions, oxidative imbalance or immune mediated factors. HD-related factors include foreign body exposure (AV grafts, catheters), membrane biocompatibility, type of filter and dialysis quality. The traditional biomarkers such as white blood cell (WBC) count, erythrocyte sedimentation rate, and C-reactive protein (CRP) are affected by inflammatory response elicited during the process of $\mathrm{HD}$ and uremia. Hence these biomarkers are not considered sensitive and specific in patients on maintenance HD. PCT is considered to be a specific biomarker for bacterial sepsis, as the noninfectious inflammatory stimuli required to induce inflammatory response need to be very potent to release PCT by the tissues.

There is sufficient data reporting the clinical significance of PCT in discriminating bacterial infections from non-bacterial infections including systemic inflammatory response syndrome in patients with normal kidney function. ${ }^{15}$ Few studies support its diagnostic utility in patients on HD, however data is lacking regarding its cut off level in HD patients without signs of infection. The study was undertaken to evaluate normal serum levels of PCT in patients undergoing HD.

\section{Patients and Methods: \\ Design and Setting: Prospective, observational clinical study at a university hospital.}

The study included 82 consecutive ESKD patients undergoing maintenance HD. The patients aged between 16 and 70 years. There was no major or minor surgical procedure or clinical evidence of infection in the three weeks preceding the study. None of these patients had any malignancy or immunologic disorder. HD was undertaken thrice weekly. Bicarbonate buffer based dialysate was used. In HD, polysulfone dialyzer (Hemoflow F6, Fresenius, Germany) was used. Low molecular weight heparin was used for anticoagulation. Blood flow rate was in between $250-350 \mathrm{ml} / \mathrm{min}$. Ultrafiltration rate was in the range of $250-1000 \mathrm{ml} / \mathrm{hr}$. Simple reverse osmosis was applied for water treatment. Periodic surveillance cultures showed no growth in any samples taken from the dialysate solution.

Interventions: Venous blood samples were drawn before the start of the HD sessions. PCT was assayed by ECLIA (electrochemiluminescene immunoassay analyzer) method (E411 by Roche, Indiana, USA).

Statistical Analysis: Data was analyzed by using statistical package for social sciences, SPSS 25 (IBM, New York, USA). Normality was checked by Shapiro Wilk test. Mean, median and range were compared for quantitative variable and frequency and percentages were calculated for qualitative variables. Comparison of PCT with gender, age group and Diabetes Mellitus was done. Spearson' rank correlation was applied to see relationship between quantitative variables with respect to PCT.

\section{Results:}

There were 47 males and the average age of patients in the study was $50 \pm$ years. The main cause of CKD was Diabetic Nephropathy (34\%). The optimized cut off level derived for serum PCT was found to be $0.62 \mathrm{ng} / \mathrm{ml}$ in patients undergoing maintenance HD.

Table 1: Characteristics of 82 maintenance hemodialysis patients included in the study. 


\begin{tabular}{|l|c|}
\hline \multicolumn{1}{|c|}{ Variables } & $\mathrm{n}(\%)$ \\
\hline & \\
\hline Age(years $)^{\circ}$ & $50.74 \pm 15.06,52(6-79)$ \\
\hline PCT( ng/ml) $\mathrm{o}$ & $0.62 \pm 0.75,0.37(0.05-3.93)$ \\
\hline Dx Duration(Months) $\mathrm{o}$ & $26.56 \pm 18.9,24(2-70)$ \\
\hline Gender & \\
\hline Male & \\
\hline Female & $47(57.3)$ \\
\hline Diabetes Mellitus & $35(42.7)$ \\
\hline Yes & \\
\hline No & $34(41.5)$ \\
\hline OMean, Median (Range) & $48(58.5)$ \\
\hline
\end{tabular}

\section{Discussion:}

Our study showed that PCT levels in the absence of infection among our HD patients was higher compared to the reported for normal renal function. Our study is in consistent with other studies in HD patients. ${ }^{16,17}$ Procalcitonin is mainly produced in the parathyroid glands and correlates with the levels of calcitonin, however in sepsis, it is produced from liver, lungs and intestine. $^{18}$ It has been shown to be a reliable marker of bacterial infection except in Candida Tropicalis and Legionella sepsis. ${ }^{15,18}$ It has been shown to be the most sensitive and reliable indicator of bacterial infections as discussed in an editorial by Falcone and Menichetti. ${ }^{19}$

Serum PCT below .1ng/ml is normally found in healthy individuals. There is sufficient data reporting PCT as an accurate and specific tool for diagnosing bacterial sepsis in patients with normal renal functions. ${ }^{4,8,10,15}$ In patients with renal impairment the clearance is decreased, and levels may not be as reliable and a combination of clinical picture and other markers of inflammation and infection may point towards the presence of bacterial infection.38 Similarly, significantly high levels of PCT do correlate better with presence of bacterial infection than other markers in patients with catheter related blood stream infections. ${ }^{16,21}$ Majority of the HD patients initiate dialysis with temporary vascular access and therefore infections are a common occurrence. ${ }^{22}$

The utility of PCT as a diagnostic test for bacterial infections in HD patients is controversial due to various reasons. In HD patients, the conventional laboratory markers like ESR and CBC are affected by uremic milieu and process of $\mathrm{HD}^{23,24}$ Clearance and adsorption to the HD filters especially high flux may lead to lower levels after dialysis. Nevertheless, levels drawn before HD session significantly correlate with bacterial infections. ${ }^{16,17,19}$

Table 2: Comparison of PCT with respect to age, gender, Diabetes and duration $(n=82)$ 
Procalcitonin and ESKD

\begin{tabular}{|c|c|c|}
\hline $\begin{array}{c}\text { Variables } \\
\text { (Number of Pts) }\end{array}$ & $\begin{array}{c}\text { PCT (ng/ml) } \\
\text { Mean } \pm \text { SD, Median (Range)(ng/ml) }\end{array}$ & P-Value \\
\hline \multicolumn{3}{|l|}{ Gender } \\
\hline $\begin{array}{l}\text { Male } \\
(47) \\
\end{array}$ & $0.664 \pm 73,0.44(0.10-3.64)$ & \multirow[t]{3}{*}{0.15} \\
\hline $\begin{array}{l}\text { Female } \\
(35)\end{array}$ & $0.57 \pm 0.80,0.35(0.05-3.93)$ & \\
\hline \multicolumn{2}{|l|}{ Age Group } & \\
\hline $\begin{array}{l}\leq 50 \text { years } \\
(36)\end{array}$ & $0.60 \pm 0.49,0.43(0.10-3.64)$ & \multirow{3}{*}{0.41} \\
\hline $\begin{array}{l}50 \text { years } \\
(46)\end{array}$ & $0.64 \pm 0.84,0.35(0.05-3.93)$ & \\
\hline \multicolumn{2}{|l|}{ Diabetes Mellitus } & \\
\hline \begin{tabular}{|l|} 
Yes \\
$(34)$ \\
\end{tabular} & $0.68 \pm 0.79,0.35(0.05-3.14)$ & \multirow[t]{3}{*}{0.92} \\
\hline \begin{tabular}{|l} 
No \\
$(48)$
\end{tabular} & $0.58 \pm 0.73,0.43(0.08-3.93)$ & \\
\hline \multicolumn{2}{|l|}{ Duration } & \\
\hline $\begin{array}{l}\leq 24 \text { months } \\
(50)\end{array}$ & $0.56 \pm 0.67,0.33(0.05-3.14)$ & \multirow{2}{*}{0.06} \\
\hline \begin{tabular}{|l}
24 months \\
$(32)$
\end{tabular} & $0.72 \pm, 0.46(0.14-3.93)$ & \\
\hline \multicolumn{3}{|c|}{ Mann-Whitney test was applied. } \\
\hline \multicolumn{3}{|c|}{ P-value $\leq 0.05$, considered as significant. } \\
\hline
\end{tabular}

In contrast to other studies mentioned we wanted to establish levels of PCT among HD patients who did not have any indication of infection with usual inflammatory markers. We therefore propose that among HD patients the level of PCT is around $0.65 \mathrm{ng} / \mathrm{ml}$ as compared to a normal of $0.02 \mathrm{ng} / \mathrm{ml}$. The limitation of our study is the absence of a comparison group with active bacterial infection and calls for further studies to confirm our finding.

\section{Conclusion:}

It was observed that ESKD patients on maintenance HD had higher PCT levels $(.622 \mathrm{ng} / \mathrm{ml})$ than the standard cut off of $.5 \mathrm{ng} / \mathrm{ml}$ for the presence of bacterial infection in patients with normal kidney functions. We conclude that a higher cutoff value of PCT to be considered as a useful marker of sepsis in HD patients.

\section{Disclosure Statement}

The authors have no conflict of interest to declare

\section{Funding Sources:}


The study was supported by Liaquat National Hospital Research Committee. The funders have no role in the study design, data collection and analysis, the decision to publish and the preparation of this paper.

\section{References:}

1. M. Assicot, C. Bohuon, D. Gendrel Raymond J, Guilbaud J, Bohuon CHigh serum procalcitonin concentrations in patients with sepsis and infection. Lancet 1993 Feb 27; 342 (8844): 515-518.

2. Castelli GP, Pognani C, Cita M, Stuani A, Sgarbi L, Paladini R. Procalcitonin, C-reactive protein, white blood cells and SOFA score in ICU: diagnosis and monitoring of sepsis. Minerva Anesthesiol. 2006;72(1-2): 69-80.

3. Rey C, Los Arcos M, Concha A, Medina A, Prieto S, Martinez P. Procalcitonin and C-reactive protein as markers of systemic inflammatory response syndrome severity in critically ill children. Inten Care Med, Intensive Care Med (2007) 33:477-484

4. Sauer M, Tiede K, Fuchs D, Gruhn B, Berger D, Zintl F. Procalcitonin, C-reactive protein, and endotoxin after bone marrow transplantation: identification of children at high risk of morbidity and mortality from sepsis. Bone Marrow Transplantation. 2003; 31(12): 1137-1142.

5. Aikawa N, Fujishama S, Endo S, Sekine I, Kogawa K, Yamamoto Y.et al. Multicenter prospective study of procalcitonin as an indicator of sepsis. Journal of infection and Chemotherapy. 2005; 11(3): 152-159.

6. The Process Investigators. A randomized trial of protocol-based care for early shock. N Engl J Med. 2014; 370: 1683-1693.

7. ARISE Investigators. The goal directed resuscitation for patients with early septic shock. N Engl J Med. 2014 Oct 16; 371 (16): 1496-506.

8. Schuetz P, Batschearoff M, Dusemund F, Albrich W, Bürgi U, Maurer M, et al. Effectiveness of a procalcitonin algorithm to guide antibiotic therapy in respiratory infections outside of study conditions: a post-study survey. Europ J Clin Microbiol Infect Dis. 2010; 29(3): 269-277.

9. Sitter T, Schmidt M, Schneider S, Schiffl H. Differential diagnosis of bacterial infection and inflammatory response in kidney disease using procalcitonin. Journal of Nephrology. 2002;15(3): 297-301.

10. Herget-Rosenthal S, Marggarf G, Pietruck F, Hüsing J, Strupat M, Philipp Tet al. Procalcitonin for accurate detection of infection in HD. Nephrology Dialysis Transplantation. 2001; 16(5): 975-979.

11. Dahaba AA, Rehak PH, List WF. Procalcitonin and C-reactive protein plasma concentrations in nonseptic uremic patients undergoing HD. Intensive Care Medicine. 2003;29(4):579-583.

12. Dagher GB, Harmouche E, Jabbour E, Bachir R, Zebian D, Cheb RB. Sepsis in HD patients. BMC Emergency Medicine. 2015;15:30-36.

13. Kayser J, Youming P, Lara B, Flakoll PJ, Levenhagen D, Hakim RM. et al. Inflammatory signals associated with HD. Kidney International. 2002;62(4):1523-1775.

14. Rosa J, Patrocinio R-B. Jua M. Inflammatory Syndrome in Patients on Hemodiaysis. JASN December 2006;17(suppl3):S2744-S280.

15. Schuetz P, Briel M, Christ-Crain M, Stolz D, Bouadma L, Wolff M, et al. Procalcitonin to guide initiation and duration of antibiotic treatment in acute respiratory infections: an individual patient data meta-analysis. Clin Infect Dis.2012;55:651-662.

16. Imam MH, Gamal E. Procalcitonin level as a surrogate for catheter-related blood stream infection among hemodialysis patients. 2017;18(6):498-502

17. Schneider R, Cohen MJ, Benenson S, Duchin O, Haviv YS, Elhalel-Darnitski M et.al. Procalcitonin in the intensive care unitProcalcitonin in hemodialysis patients presenting with fever or chills to the emergency department. Intern Emerg Med. 2020;15(2):257-262.

18. S. Großmann - S. Schroll - M. Pfeifer. Procalcitonin in the intensive care unit. Med Klin Intensivmed Notfmed. 2020 Jun $29: 1-8$. (German)Procalcitonin in the intensive care unitProcalcitonin in the intensive care unitProcalcitonin in the intensive care unit

19. Falcone M, Tiseo G, Menichetti F. Interpreting procalcitonin in patients undergoing hemodialysis:a reliable or a misleading marker? Intern Emerg Med. 2021;16(1):11-13. 
20. Amour J, Birenbaum A, Langeron O, Le Manach Y, Bertrand M, Coriat P et al. Influence of renal dysfunction on the accuracy of procalcitonin for the diagnosis of postoperative infection after vascular surgery. Crit Care Med 2008;36:1147 - 54.

21. Luzzani A, Polati E, Dorizzi R, Rungatscher A, Pavan R, Merlini A. Comparison of procalcitonin and Creactive protein as markers of sepsis. Crit Care Med. 2003;31(6):1737-1741.

22. Sabir O, Riaz MM, Rafique K, Anjum N, Abbas A, Akram M, et.al. Fistula First - Are We There Yet? A Multicenter study. Pak J Kidney Dis 2017;1(3):21-26

23. Behzad H. MD. C-reactive protein and other markers of inflammation in HD patients Caspian J of Intern Med. 2013 Winter; 4(1): 611-616.

24. Gabriela C. Bengt L. Peter S. Chronic inflammation in end-stage renal disease and dialysis. Nephrol Dial Transplant 2018;33 (suppl 3): iii35-iii40. 